\title{
Krzysztof Żochowski
}

Uniwersytet w Białymstoku e-mail: krzysiekz1991@gmail.com telefon: +48 857457172

DOI: 10.15290/mhi.2014.13.01.15

\section{Zagadnienie praworządności na łamach „Prawa i Życia” w 1956 roku}

\author{
SUMMARY
}

The issue of law-abidingness in 1956 "The Law and the Life"

A short-term change of the political climate in Poland in 1956 gave an opportunity to start an open discussion (as the realities of that time) about the condition of obeying the law, proper understanding of the rule of law and "errors of the past". A major part of this discussion went on pages of new bi-weekly magazine "Law and Life" created by the Association of Polish Lawyers. In the course of this discussion, the Soviet patterns which blurred the meaning of those terms, were left. Newly defined, they described numerous contradictions prior to 1956. Subsequently the discussion focused on the problem of ensuring law-abideness in the judiciary and the administration.

Key words: "Law and Life", rule of law, People's Republic of Poland, Polish October 1956, Association of Polish Lawyers

Słowa kluczowe: „Prawo i Życie”, praworządność, Polska Republika Ludowa, Polski październik 1956, Zrzeszenie Prawników Polskich

\section{Wprowadzenie}

Celem artykułu jest zaprezentowanie dotychczas nie w pełni zbadanego bliżej aspektu procesów i przemian, które miały miejsce w PRL w drugiej połowie 1956 roku. Pomimo że dyskusja specjalistów piszących na łamach „Prawa i Życia” była poświęcona praworządności jako problemowi bliskiemu prawnikom, to pod jej pozorem krytykowano w wielu miejscach rzeczywistość państwa totalitarnego, jego działania i ideologię. Tak daleko idące głosy dezaprobaty dla dotychczasowego stanu nie byłyby możliwe bez „odwilży”, ale jednocześnie wielokrotnie były w jej awangardzie. Wiąże się to z momentem, kiedy wspomniane czasopismo zaczęło się ukazywać oraz historią jego powstania. Na szczególną uwagę zasługuje fakt, że większość autorów studia prawnicze odbyło na uniwersytetach II RP i wówczas zdążyło rozpocząć pracę zawodową 
lub naukową. W roku 1956 wielu z nich, mimo tej przeszłości, było blisko związanych z władzą, pracowało zawodowo lub było pracownikami naukowymi szkół wyższych.

Zagadnienie praworządności, będąc przedmiotem różnorodnych koncepcji teoretycznych, jest jednocześnie bliskie, choć bardziej jako slogan czy hasło, każdemu obywatelowi mającemu styczność z organami administracji publicznej i wymiarem sprawiedliwości. Zajmujące jest również pytanie, kim byli ludzie, którzy tak dobrze sobie radzili w rzeczywistości stalinowskiej Polski, a później dali wyraz dążeniu do daleko idącej zmiany i zaczęli o tym mówić otwarcie, gdy tylko pojawiła się taka możliwość. Tytułem przykładu warto wspomnieć apele o poprawę stanu praworządności, wychodzące spod pióra czterech sędziów sekcji tajnej Sądu Najwyższego, której działalność opierała się na negacji podstawowych praw oskarżonego w procesie karnym.

Wszystkie wspomniane elementy w sposób najbardziej wyrazisty występowały przede wszystkim $w$ roku 1956. Ograniczenia wypływające $z$ tej formy prezentacji wyników badań zmuszają do pominięcia, bądź jedynie zasygnalizowania, wielu kolejnych wątków zasługujących na pełniejsze zbadanie. Należy do nich np. przyjęcie i szybkie zarzucenie po 1956 roku koncepcji „ostrzy praworządności"1.

O znaczeniu toczącej się dyskusji świadczy również osobista pozycja prawników zabierających w niej głos. Pięciu spośród nich było sędziami Sądu Najwyższego, kilku - pracownikami szkół wyższych, Gustaw Auscaler był rektorem Wyższej Szkoły Prawniczej im. Teodora Duracza w Warszawie, Marian Mazur został w czerwcu 1956 roku zastępcą Prokuratora Generalnego, a Jerzy Jodłowski w 1957 - wicemarszałkiem Sejmu.

\section{Pojęcie praworządności w PRL przed 1956 rokiem}

Rozumienie praworządności, a także określenie i realizacja wypływających z niej dyrektyw szczególnych, było jednym $\mathrm{z}$ przewodnich tematów w roku 1956. W tym czasie Polska Ludowa wychodziła z okresu „błędów i wypaczen". Władza przyznawała się do nich pod wpływem "odwilży”. Konsekwencją tego była dyskusja o wielu podstawowych problemach związanych $\mathrm{z}$ błędami przeszłości. A jednym z nich o niebagatelnym znaczeniu była właśnie praworządność, którą rozumiano jednak specyficznie. Złożoność tego pojęcia wypływała z uwarunkowanego ideologicznie rozróżniania wówczas jej podtypów: burżuazyjnego i socjalistycznego, a także ludowego oraz rewolucyjnego².

1 A. Lityński, O praworządności ludowej w Polsce 1944-1956 teoretycznych uwag kilka, [w:] Z dziejów prawa, cz. 8, Katowice 2006, s. 165-182.

2 Na rozróżnianie praworządności ludowej i socjalistycznej wskazuje A. Lityński: „W Polsce począt- 
Konstytucja Polskiej Rzeczypospolitej Ludowej ${ }^{3}$ proklamowała zasadę praworządności ludowej w art. 4 ust. 2: „Ścisłe przestrzeganie praw Polskiej Rzeczypospolitej Ludowej jest podstawowym obowiązkiem każdego organu państwa i każdego obywatela", jednocześnie była wyrażona również w preambule ${ }^{4}$. Zaakcentować należy, iż jedną z cech charakterystycznych ówczesnego rozumienia tego pojęcia było wiązanie go $\mathrm{z}$ obowiązkiem przestrzegania prawa przez wszystkich obywateli, a nie tylko organy państwa.

Samo rozumienie praworządności w Polsce po wojnie - aż do 1956 roku - było w znaczącym stopniu przesycone wpływem ideologii komunistycznej i wzorców płynących z ZSRR. Prawnicy w 1953 roku na konferencji PAN wyrażali pogląd, iż "Osiągnięcia partii i rządu ZSRR w walce o ugruntowanie praworządności rewolucyjnej, zdobycze radzieckiej nauki o praworządności są dla nas drogowskazem w walce o ugruntowanie praworządności w Polsce Ludowej" $^{\prime}$. Podstawowym zabiegiem było rozróżnianie praworządności ludowej i burżuazyjnej, z wieloaspektową krytyką tej ostatniej, oraz wskazywanie ich treści klasowej. Praworządność ludowa była rozumiana bardzo szeroko jako zasada działania władzy ludowej, odnosiła się do całokształtu życia społecznego, politycznego i gospodarczego; polegała na jej „ścisłym i bezwzględnym przestrzeganiu przez wszystkie organy władzy i administracji państwowej oraz przez poszczególnych obywateli praw Polskiej Rzeczypospolitej Ludowej, które są wyrazem interesów i woli ludu pracującego"6.

Ważnym elementem rozumienia owej instytucji było wskazywanie, zgodnie z przejętymi z ZSRR wzorcami, ostrzy i zadań praworządności rewolucyjnej, a następnie ludowej, mających na celu niszczenie wrogów i zwalczanie zamachów na państwo socjalistyczne i „interesy mas pracujących”. U zarania Polski Ludowej ostrza te były wymierzone we wrogów władzy ludowej i ustroju nowego państwa ludowego - faszyzm, imperializm i ich agentów wewnątrz kraju, za których uznawano m.in. WiN, PSL i WRN; takim ostrzem był - jak twier-

kowo mieliśmy tylko praworządność ludową, wszak byliśmy krajem jedynie demokracji ludowej, do socjalizmu zaledwie zdążającym. Mogła to być jednak rewolucyjna praworządność ludowa; praworządność socjalistyczna pojawiała się już, ale sporadycznie, wyjątkowo. Dopiero gdy w konstytucję PRL - w miejsce określenia, iż jest PRL państwem demokracji ludowej - wpisano, że jest państwem socjalistycznym [Ustawa z dnia 10 lutego 1976 r. o zmianie Konstytucji Polskiej Rzeczypospolitej Ludowej (Dz. U. 1976 nr 5 poz. 29) - K.Ż.], dopiero wówczas pojawił się termin praworządność socjalistyczna w odniesieniu do systemu u nas panującego", A. Lityński, O pojmowaniu praworządności socjalistycznej w Polsce Ludowej, "Czasopismo Prawno-Historyczne" [dalej: CPH] 2007, t. LIX, z. 1, s. 113-127.

Dz. U. 1952 nr 33, poz. 232.

4 M. Kallas, A. Lityński, Historia ustroju i prawa Polski Ludowej, Warszawa 2000, s. 132.

5 H. Podlaski, G. Auscaler, M. Jaroszyński, G. L. Seidler, J. Wróblewski, Praworzadność ludowa w świetle Konstytucji Polskiej Rzeczypospolitej Ludowej, [w:] Zagadnienia prawne konstytucji Polskiej Rzeczypospolitej Ludowej. Materiaty Sesji Naukowej PAN 4-9 lipca 1953 r., red. G. Auscaler, t. 1, Warszawa 1954, s. 349.

6 Ibidem, s. 341. 
dzono - m.in. Dekret PKWN z 30 października 1944 roku o ochronie Państwa (Dz. U. 1944 nr 10, poz. 50)7 . W następnej fazie zaś, ostrza te były skierowane w licznych wrogów klasowych ustroju, zgodnie z twierdzeniem Stalina o zaostrzaniu się walki klasowej w miarę budowy socjalizmu. Obronę państwa ludowego przed wszelkimi zakusami wroga uważano za istotny element treści pojęcia praworządności ${ }^{8}$.

\section{Proces zmiany rozumienia pojęcia praworządności oraz powstanie "Prawa i Życia”}

Śmierć Józefa Stalina w 1953 roku zapoczątkowała okres zmian w ZSRR oraz w jego państwach satelickich. Przejawem tego miało być stopniowe ograniczenie rozmiarów represji oraz kolegialne przywództwo. Najważniejsze było ujawnienie i potępienie części zbrodni Stalina na XX Zjeździe KPZR (14-25 lutego 1956 roku) przez Nikitę Chruszczowa9 . Proces ten znalazł również odzwierciedlenie w PRL, przy czym jedną z jego przyczyn, bądź też symptomem nadchodzącej już zmiany, była ucieczka na Zachód wicedyrektora X Departamentu MBP, dbającego o czystość partyjnych szeregów, ppłka Józefa Światły. Był on autorem szokujących społeczeństwo relacji, ujawnianych od 1954 roku na falach Rozgłośni Polskiej Radia Wolna Europa ${ }^{10}$.

W sferze czasopism prawniczych pierwsze oznaki odwilży można było zauważyć na IV Zjeździe Zrzeszenia Prawników Polskich [ZPP] ${ }^{11}$ w grudniu 1955 roku, kiedy to periodykom prawniczym wyznaczono zadanie bycia platformą walki o umocnienie praworządności ludowej oraz o podniesienie

7 Ibidem, s. $352-354$.

8 Ibidem, s. 359.

9 Rok 1956 był opóźnioną konsekwencją znaczących zmian zachodzących w ZSRR po śmierci Józefa Stalina, gdzie już w kwietniu 1953 r. w prasie zaczęły pojawiać się zarzuty pod adresem organów bezpieczeństwa, И. А. Исаев, История государства и права России, Москва 2004, s. 723.

10 Zob. Z. Błażyński, Mówi Józef Światło. Za kulisami bezpieki i partii 1940-1955, Warszawa 1990, s. 10-17. O przyczynach ucieczki: A. Paczkowski, Trzy twarze Józefa Światly, Warszawa 2009, s. 178-188.

11 „Zrzeszenie Prawników Polskich zostało powołane w maju 1945 r. jako Zrzeszenie Prawników Demokratów. Zmiana nazwy nastąpiła w 1950 r. Zrzeszenie postawiło sobie jako zadanie: organizowanie prawników do pracy społecznej przy odbudowie demokratycznej Polski; współpracę z organizacjami państwowymi i samorządowymi w organizowaniu demokratycznego życia państwowego i gospodarczego; ugruntowanie zasad demokratycznych w prawodawstwie polskim; wypracowanie poprzez wiązanie teorii z praktyką demokratycznej polskiej myśli prawniczej; integrowanie wszystkich zawodów prawniczych; podnoszenie kwalifikacji zawodowych prawników oraz zapewnienie im należnej pozycji w życiu politycznym i społecznym kraju, troskę o ich warunki bytowe. Od początku istnienia Zrzeszenie dążyło do tego, aby stać się organizacją obejmującą ogół prawników polskich. Pod przewodnictwem prof. dr Jerzego Jodłowskiego, ówczesnego wicemarszałka Sejmu, ZPD przekształciło się w ZPP. Przez kilka lat prezesem ZPP był prezes SN, Marian Mazur, a następnie prof. dr Zbigniew Resich, I Prezes Sądu Najwyższego", http://www.zpp.org.pl/o_zrzeszeniu.html (1.02.2013). 
autorytetu prawa, a także udostępnienie swoich łamów dla twórczych dyskusji w sprawach spornych i wątpliwych. Efektem negatywnej oceny działalności licznych dotychczasowych czasopism prawniczych było pojawienie się już w połowie 1956 roku nowego dwutygodnika prawno-społecznego „Prawo i Życie” $^{\prime}[\mathrm{PiZ}]^{12}$. Jako organ ZPP, zastąpił w tej roli „Państwo i Prawo”, który stał się periodykiem Komitetu Nauk Prawnych PAN ${ }^{13}$.

Dwutygodnik stał się jednym z moderatorów dyskusji o praworządności. Zaczął się ukazywać 6 maja 1956 roku, a wśród jego zadań wyróżniono także zabezpieczenie socjalistycznej praworządności ${ }^{14}$. W roku 1956 to hasło stało się kluczem do rozważań o sprawiedliwości w dobie „odwilży”15.

„Prawo i Życie” było pismem prawniczym o dużym znaczeniu. Wynikało to $\mathrm{z}$ faktu, że było organem ZPP, zrzeszającego większość prawników z całego kraju. Najlepszą z kart zapisało sobie właśnie w 1956 roku. Późniejsze zaś dzieje pokazują, iż w kolejnych okresach przełomów działało zgodnie z linią partii i rządu, choć jego rola była niejednokrotnie duża, np. odegrało ważną rolę w dyskusjach nad projektem kodeksu rodzinnego i opiekuńczego ${ }^{16}$. Przestało się ukazywać już w wolnej Polsce w 2001 roku. Samo ZPP istnieje nadal.

Pierwszym redaktorem „Prawa i Życia” był sędzia Sądu Najwyższego, Aleksander Bachrach"17; poza nim do kolegium redakcyjnego należeli: Jan Frankowski (poseł na Sejm PRL I-V kadencji), Jerzy Gembicki (sekretarz), Ignacy Iserles (sędzia SN), Jerzy Jodłowski (przewodniczący ZG ZPP, sę-

12 D. Maksimiuk, W sprawie demokratyzacji wymiaru sprawiedliwości. "Prawo $i$ Życie" $i$ inne czasopisma prawnicze w roku 1956 w Polsce, CPH 2011, t. LXIII, z. 1, s. 295.

13 „Zarząd Główny Zrzeszenia Prawników Polskich oraz Komitet Nauk Prawnych Polskiej Akademii Nauk uznały, że Komitet Nauk Prawnych winien dysponować czasopismem, które by służyło dalszemu rozwojowi nauk prawnych. Wobec tego, że miesięcznik «Państwo i Prawo», dotychczasowy organ ZPP zyskał sobie charakter czasopisma naukowego - Zarząd Główny ZPP i Prezydium KNP postanowiły przekształcić «Państwo i Prawo» w organ Komitetu Nauk Prawnych, a w przyszłości organ Instytutu Nauk Prawnych PAN. W wyniku powyższego «Państwo i Prawo» ukazywać się będzie od miesiąca maja br. jako organ KNP PAN. Prezydium ZG ZPP", Komunikat, "Prawo i Życie" (dalej: PiŻ) 1956, nr 1, s. 7.

14 Informacja o tygodniku prawno-społecznym "Prawo $i$ Życie", [w:] Prawo i prawnicy w trzydziestolecie Polskiej Rzeczpospolitej Ludowej (materiały z narady zrzeszeń prawniczych europejskich krajów socjalistycznych), Warszawa 1974, s. 81.

15 D. Maksimiuk, Rok 1956 w Polsce: sqdy, prokuratury, prawo karne, Białystok 2011 (rozprawa doktorska obroniona na Wydziale Prawa UwB, niepublikowana).

16 Zob. P. Fiedorczyk, Kilka uwag o publicznej dyskusji nad prawem rodzinnym w projekcie kodeksu cywilnego z 1960 roku, [w:] Filozofia Marii Szyszkowskiej, red. A. Kryniecka, Białystok 2012, s. 360-380.

17 Aleksander Bachrach (1911-1979) - sędzia Izby Karnej Sądu Najwyższego [SN] oraz bardzo aktywny sędzia sekcji tajnej, powołany przez ministra sprawiedliwości do pełnienia obowiązków sędziego SN, w 1953 r. otrzymał nominację, odwołany w marcu 1954 r., w maju 1957 r. powołany ponownie, A. Bereza, Sąd Najwyższy w Polsce Ludowej, [w:] Sąd Najwyższy Rzeczypospolitej Polskiej. Historia i wspótczesność. Księga Jubileuszowa 90-lecia Sądu Najwyższego 1917-2007, red. A. Korobowicz, Toruń 2007, s. 228; idem, Sąd Najwyższy w latach 1945-1962. Organizacja i działalność, Warszawa 2012, s. 163. 
dzia SN, prof. UW), Leszek Kubicki (pracownik INP PAN), Marian Mazur (sędzia SN / zastępca Prokuratora Generalnego i wiceprezes Głównej Komisji Arbitrażowej), Marian Muszkat, Jerzy Sawicki (prof. UW), Jarosław Semkow, Adam Wendel, Jerzy Winiewski ${ }^{18}$. Jak widać, do kolegium redakcyjnego weszły osoby zajmujące bardzo wysoką pozycję w hierarchii zawodowej i mające bezpośrednią styczność z najwyższymi czynnikami politycznymi państwa.

Dzieje pisma i toczonych w nim polemik otworzył artykuł Gustawa Auscalera, przedstawiającego się jako szermierz praworządności. Autor ten był odpowiedzialny za zbrodnie sądowe. $W$ tym miejscu warto wspomnieć, iż pełniąc obowiązki sędziego sekcji tajnej SN z powołania Ministra Sprawiedliwości, był razem z Emilem Merzem i Igorem Andrejewem (późniejszym profesorem UW) członkiem składu orzekającego, który zatwierdził w II instancji wyrok śmierci na generała Augusta Emila Fieldorfa w 1952 roku (sygnatura akt: IV K 311/51). Następnie ten sam skład negatywnie zaopiniował prośbę o ułaskawienie generała. Był również rektorem Wyższej Szkoły Prawniczej im. Teodora Duracza, kształcącej w przyśpieszonym trybie kadry prawnicze dla Polski Ludowej, ostatecznie w grudniu 1957 roku wyjechał do Izraela ${ }^{19}$.

Nawiązując do przełomowego znaczenia XX Zjazdu KPZR, autor zauważał, że zjazd niesłychanie podniósł rolę prawa i prawników w społeczeństwie, napawając ich świadomością wagi i znaczenia. Postulował uczynienie z prawa, które uważał za par excellence polityczne, samodzielnego czynnika, co miało oznaczać, że prawo nie powinno być tylko narzędziem realizacji określonej doraźnej polityki, lecz powinno być bytem samodzielnym, tworzonym starannie i realizującym wartości wyższe jak np. sprawiedliwość. Za zadanie prawników uważał realizowanie ideałów socjalizmu oraz troskę o zgodność praktyki i teorii. Górnolotnie konstatował, iż "Socjalizmowi można służyć tylko prawdą" ${ }^{\prime 20}$. Tekst ten w momencie ukazania się był odważną deklaracją nowego prądu myślowego, lecz napisany był językiem w pełni zakorzenionym w stylu i metaforyce stalinowskiej oraz nie atakował wprost przeszłości. W porównaniu z kolejnymi głosami w tej dyskusji można go określić jako ostrożny wstęp do głosów znacznie odważniejszych.

Znacznie dalej idące i bardzo przekrojowe postulaty przedstawił w tej materii członek kolegium redakcyjnego, poseł Jerzy Jodłowski²1. Również on miał

18 D. Maksimiuk, W sprawie demokratyzacji..., s. 297.

19 Gustaw Auscaler - prokurator Prokuratury Generalnej, następnie powołany przez Ministra Sprawiedliwości do pełnienia obowiązków sędziego Sądu Najwyższego, w 1953 r. otrzymał nominację na sędziego Sądu Najwyższego, po czym w marcu 1954 r. został odwołany, zmarł 10 listopada 1965 r., A. Bereza, Sąd Najwyższy w latach 1945-1962..., s. 229; idem, Sąd Najwyższy w Polsce Ludowej..., s. 224-225; M. Płużyński, Stalinowscy uciekinierzy, „Najwyższy Czas” 2009, nr 48, s. XXXVI.

20 G. Auscaler, Myśli na co dzień, PiŻ 1956, nr 1, s. 1.

21 Jerzy Jodłowski (1909-2000) - polski prawnik, specjalizujący się postępowaniu cywilnym, w latach 1948-1959 przewodniczący Zarządu Głównego ZPP, od 1951 r. profesor nadzwyczajny na Wydziale 
niechlubną kartę. Pisał na wstępie: „Aby walka o praworządność ludową, o zaufanie mas w praworządność i wymiar sprawiedliwości mogła być zwycięsko wygrana - trzeba po pierwsze zlikwidować błędy przeszłości, a po drugie stworzyć trwałe gwarancje praworządności na przyszłość" 22 . Krokiem na drodze do praworządności miało stać się, według niego, nadanie prokuraturze odpowiedniej pozycji i stworzenie jej gwarancji umożliwiających rzeczywiste sprawowanie nadzoru nad milicją, organami bezpieczeństwa oraz administracją. Podkreślał duże znaczenie stanu ustawodawstwa, który nie był przez niego oceniany najwyżej. Postulował zwłaszcza sfinalizowanie projektów kodyfikacyjnych, usunięcie wewnętrznych sprzeczności systemu prawnego, podniesienie poziomu techniki legislacyjnej, powstrzymanie inflacji przepisów prawnych oraz konieczność publikacji aktów zawierających normy powszechnie obowiązujące ${ }^{23}$.

W ramach obszernej dyskusji nad projektem kodeksu karnego wprost do kwestii praworządności w prawie karnym odniósł się Władysław Wolter ${ }^{24}$, słusznie wskazując, iż „prawo karne przez swoje sankcje godzi i godzić ma $\mathrm{w}$ najżywotniejsze interesy [...] $\mathrm{Z}$ tego zaś wynika, że niepraworządność spotkać się musi z bardzo żywym potępieniem" ${ }^{25}$. Jako środki w celu zabezpieczenia praworządności wskazywał: układ ustawy minimalizujący szanse jej niepraworządnego stosowania; sposób stosowania prawa zgodny z odpowiednio ukształtowanymi przepisami postępowania oraz dobór właściwych ludzi reprezentujących wysoki poziom intelektualny i moralny.

Ignacy Iserles ${ }^{26}$ wskazał na rolę adwokatury. Krytykował praktykę ograniczania inicjatywy obrońcy, czynienia z niego „pomocnika” prokuratora i sądu, gdyż wówczas - jak twierdził - prawo do obrony staje się fikcją. Jego zdaniem najlepiej realizacji praworządności mogli przysłużyć się adwokaci żarli-

Prawa UW, w latach 1951-1960 wiceprzewodniczący Międzynarodowego Stowarzyszenia Prawników Demokratów, od 1952 r. członek Komitetu Nauk Prawnych PAN, sędzia Izby Cywilnej SN w latach 1949-1967, brał aktywny udział w pracach kodyfikacyjnych; od $1945 \mathrm{r}$. członek SD, poseł do Krajowej Rady Narodowej, Sejmu Ustawodawczego oraz Sejmów I, II i III kadencji, w latach 1957-1961 wicemarszałek Sejmu, A. Bielecki, Jerzy Jodłowski 1909-2000, [w:] Profesorowie Wydziału Prawa i Administracji Uniwersytetu Warszawskiego 1808-2008, red. G. Bałtruszajtys, Warszawa 2008, s. $188-191$.

22 J. Jodłowski, Aby praworządność nie była tamana [Z przemówienia na VIII sesji sejmowej], PiŻ 1956, nr 1, s. 1 .

23 Ibidem.

24 Władysław Wolter (1897-1986) - polski prawnik, specjalista z zakresu prawa karnego materialnego, profesor Uniwersytetu Jagiellońskiego w latach 1928-1967, od 1945 członek PAU i od 1967 - PAN. Jeden z twórców kodeksu karnego z 1969 r., Wielka Encyklopedia PWN, t. 29, red. nacz. J. Wojnowski, Warszawa 2005, s. 564.

26 Ignacy Iserles - jeden z aktywniejszych sędziów sekcji tajnej SN, A. Bereza, Sąd Najwyższy w latach 1945-1962..., s. 163. 
wie i rzetelnie broniący prawnie chronionych interesów swoich klientów, tym samym zmuszając sądy i prokuratorów do większej wnikliwości oraz lepszego ważenia argumentów, czyli generalnie lepszej pracy ${ }^{27}$.

Sylwester Zawadzki ${ }^{28}$ krytykował nieprzestrzeganie hierarchii aktów prawnych, zwłaszcza sprzeczność aktów wykonawczych z aktami nadrzędnymi; niewydawanie na czas aktów wykonawczych, a nawet ustaw pozwalających realizować obywatelom swoje konstytucyjne prawa. Akcentował, iż „każdy tego rodzaju fakt podrywa zaufanie do władzy ludowej do całego procesu naprawy, które rozpoczęło III Plenum, a które zostało przyśpieszone po XX Zjeździe"29. $\mathrm{Z}$ kolei Czesław Przymusiński, wypowiadając się w tym samym tonie, wskazał na przerost prawodawstwa gospodarczego oraz występujące $w$ tej gałęzi prawa patologie, rozszerzając katalog zarzutów o nadawanie przepisom mocy wstecznej, brak regulacji intertemporalnych i vacatio legis, stosowanie niejednolitej terminologii ${ }^{30}$.

Roman Łyczywek ostro skrytykował koncepcję "ostrzy praworządności”, podsumowując: "Nie jest więc teoria ostrza praworządności niczym innym, jak próbą wykorzystania haseł i autorytetu społecznego praworządności do praktycznego tej praworządności łamania" ${ }^{\prime 31}$.

Jerzy Stembrowicz ${ }^{32}$ zwrócił z kolei uwagę na niekonsekwentnie realizowany trójpodział kompetencji - będący konsekwencją socjalistycznej zasady jednolitości władzy - mający zabezpieczyć „przestrzeganie praw obywatelskich i niezbędną równowagę zadań i obowiązków poszczególnych organów państwa". W wyniku tych zmian naczelne organy administracji działały naruszając niezależność sądów i niezawisłość sędziów. Piętnował nierespektowanie przez rząd rozdziału funkcji stanowienia prawa i rządzenia, postulując urzeczywistnienie instytucji i zasad zapisanych w konstytucji ${ }^{33}$.

$$
\text { Jerzy }
$$
m.in. W ministerstwie sprawiedliwości i redakcji "Nowego Prawa"; 1955-1961 - w Pro1963 - habilitacja, 1971 - profesor nadzwyczajny, 1981-1984 - dziekan Wydziału Prawno-Ekonomicznego Filii UW w Białymstoku, od 1987 r. profesor zwyczajny, M. Konarski, Stembrowicz Jerzy, [w:] Polski Słownik Biograficzny, t. XLIII/3, z. 178, Warszawa - Kraków 2005, s. 375-377.

I. Iserles, O adwokatach nie po raz pierwszy, PiŻ 1956, nr 2, s. 3, 5.

Sylwester Zawadzki (1921-1999) - specjalista w zakresie prawa konstytucyjnego oraz teoretyk państwa i prawa, 1963-1967 profesor Wyższej Szkoły Nauk społecznych przy KC PZPR, od 1967 r. Uniwersytetu Warszawskiego, poseł na Sejm PRL w latach 1972-1989, od 1976 r. członek PAN, uczestnik obrad okrągłego stołu, Wielka Encyklopedia PWN, t. 30, s. 288.

S. Zawadzki, Co opóźnia realizację praworzadności, PiŻ 1956, nr 4, s. 7.

C. Przymusiński, Prawa ekonomiczne sq silniejsze, PiŻ 1956, nr 4, s. 1.

Jerzy Stembrowicz (1919-1989) - prawnik konstytucjonalista, 1950 r. - doktor nauk prawnych, pracował m.in. w ministerstwie sprawiedliwości i redakcji „Nowego Prawa”; 1955-1961 - w Prokuraturze Generalnej jako wiceprokurator i naczelnik wydziału, od 1961 - na Wydziale Prawa UW, J. Stembrowicz, Granice kompetencji, PiŻ 1956, nr 8, s. 1. 
Czesław Przymusiński wypowiedział się przeciwko wąskiemu, formalistycznemu rozumieniu praworządności. Przeciwstawił mu prawdziwą - jego zdaniem - praworządność, obejmującą „obowiązek uznawania praw obywatelskich i praw człowieka". Przypomniał potrzebę instytucjonalnego zagwarantowania wysokiego poziomu naukowego działalności prawodawczej. Służyć temu miałoby skatalogowanie zasad techniki prawodawczej oraz utworzenie ośrodka złożonego z przedstawicieli nauki, naczelnych władz państwowych oraz ZPP, strzegącego praworządności in statu nascendi ${ }^{34}$. Do istoty praworządności materialnej sięgnął Zygmunt Izdebski ${ }^{35}$. Zauważył, iż sama, nawet najdoskonalsza, sądowa kontrola legalności aktów administracyjnych nie wystarczy dla jej realizacji w administracji. Ostrzegał, że „są formy naruszania praworządności, których nie da się usunąć drogą kontroli legalności aktów administracyjnych". Rozróżniał praworządność rozumianą jako rządzenie zgodnie $\mathrm{z}$ obowiązującym prawem oraz $\mathrm{w}$ szerszym ujęciu konstytucyjno-ustrojowym, jako nakaz postępowania wszystkich organów państwa zgodnie z podstawowymi zasadami ustroju, które zdobyły sobie w opinii publicznej powszechne uznanie i znalazły prawne potwierdzenie w konstytucji. Zaznaczył, iż właśnie to szerokie pojęcie praworządności jest obecne w świadomości obywateli. Jako źródło wielu naruszeń szeroko rozumianej praworządności wskazywał biurokratyczny centralizm i odwrotnie - swobodne uznanie w kwestiach, które powinny być regulowane centralnie. Wzywał: „należy zacząć przechodzić od kronikarskiego opisywania gołych faktów naruszania praworządności do wniosków ogólnych, które wskażą w jakich dziedzinach trzeba podjąć reformy w interesie szeroko pojmowanej praworządności"36.

Dyskusję toczyli specjaliści, najważniejsze jest jednak to, iż pisali oni językiem bardzo przystępnym i zrozumiałym również dla laików. Wniosek taki można wyprowadzić z fragmentów, gdy odnosili się egzemplifikacji swoich twierdzeń przykładami z dnia codziennego. Uzupełnieniem tego były zamieszczane $\mathrm{w}$ kolejnych numerach, napisane lekkim stylem reportaże oraz listy o absurdach dnia codziennego z miejsc w całym kraju. Dialog ten miał dużą wagę, gdyż w jego toku kształtowało się nowe spojrzenie na zagadnienie praworządności i sposób jej pojmowania, w znaczącym stopniu uwolniony od dyktatu ideologii. O tym, jak długą drogę przebyło wielu autorów, świadczy porów-

34 C. Przymusiński, Roboczy postulat, PiŻ 1956, nr 8, s. 1; Komisja Kodyfikacyjna przy Ministrze Sprawiedliwości została powołana zarządzeniem premiera z 23 sierpnia 1956 r. (MP nr 70 poz. 856) „§ 1. W celu opracowania podstawowych projektów kodyfikacyjnych z zakresu działalności organów wymiaru sprawiedliwości, a zwłaszcza kodeksów cywilnego i karnego, postępowania cywilnego i karnego oraz prawa o ustroju sądów i o ustroju adwokatury".

35 Dość znamiennym faktem związanym z osobą prof. Izdebskiego oraz "Prawem i Życiem” są zarzuty pod adresem pisma o dawaniu „azylu” ludziom o ciemnej przeszłości politycznej oraz epitety typu „odwilżowy”; podczas gdy Izdebski oskarżał pismo jako za mało „odwilżowe”.

Z. Izdebski, Miara praworządności, PiŻ 1956, nr 11, s. 2. 
nanie ich artykułów z w pełni wiernymi założeniom obowiązującej ideologii stanowiskami, jakie zajmowali w czasie sesji naukowej PAN poświęconej zagadnieniom prawnym Konstytucji PRL w 1953 roku.

O realnym znaczeniu teoretycznej mimo wszystko dyskusji o praworządności świadczył przebieg procesu osób oskarżonych o przestępstwa dokonane w czasie zajść czerwcowych w Poznaniu. Zdaniem Ignacego Iserlesa przebieg procesu był dowodem na to, jak duży postęp miał miejsce $\mathrm{w}$ zakresie realizacji zasad praworządności ${ }^{37}$. Autorzy nigdy w sposób otwarty nie zaatakowali obowiązującego systemu jako takiego, posuwali się jednak do bardzo odważnej krytyki różnych jego aspektów czy poczynań. Nie można jednoznacznie przesądzić, czy bardziej się tego bali, czy może uważali, że jedyną możliwą drogą jest reforma obowiązującego systemu w zakresie, $\mathrm{w}$ jakim było to możliwe $\mathrm{w}$ ówczesnych realiach politycznych i geopolitycznych. Dlatego też potępiali wydarzenia z Poznania i z nadzieją przyjęli dojście Gomułki do władzy. Złudzeniem jest sądzić, że publikowano wszystko, co autorzy pisali, a to tym samym pokazuje, że jednak partia kontrolowała skalę krytyki. Przykładem może być wstrzymanie publikacji artykułu Mariana Mazura, wzywającego do ujawnienia i ukarania winnych zbrodni okresu stalinowskiego i poddanie artykułu ocenie szefa Zarządu Sądownictwa Wojskowego, osobiście odpowiadającego za zbrodnie okresu stalinowskiego. Oczywiście wykreślił on wszystkie wzmianki o nich. Zaś członek kolegium redakcyjnego skomentował to bezpośrednio: "Jak by Marian miał to wydrukowane, co napisał, to by nie dostał stanowiska, co dostanie [zastępcy Prokuratora Generalnego - K.Ż.]"38. Praworządności poświęcone było III Plenum Zarządu Głównego ZPP (1-2 grudnia 1956 roku) ${ }^{39}$. Było ono szeroko relacjonowane na łamach „Prawa i Życia”. Jerzy Jodłowski występując na nim zwrócił uwagę na kilka problemów. Pierwszym z nich był osłabiony przejściowo nadzór judykacyjny, co było spowodowane ograniczeniem zakresu, w jakim sprawował go minister sprawiedliwości i nierozwinięcie się jeszcze w pełni nadzoru ze strony Sądu Najwyższego. Drugi, to daleko idące uaktywnienie się rad narodowych, które zaczęły przejawiać tendencje do objęcia kierownictwa nad sądami. Trzecim problemem, który wskazał była nieskuteczność prokuratorskiego nadzoru ogólnego. Zauważył, iż w poprzednim okresie Prokuratura Generalna PRL w rzeczywistości pozostawała poza kontrolą i zaproponował dyskusję nad włączeniem jej do resortu ministerstwa sprawiedliwości. W kwestii rozliczania winnych za błędy wskazał po raz kolejny na „konieczność rozróżnienia pomiędzy tymi, którzy kształtowali system, którzy umacniali go,

37 I. Iserles, W Poznaniu, PiŻ 1956, nr 12, s. 1.

38 D. Maksimiuk, W sprawie demokratyzacji..., s. 301.

39 III Plenum Zarządu Głównego ZPP, PiŻ 1956, nr 17, s. 2. 
czynili to z przekonania wewnętrznego bądź dla kariery, a tymi, którzy ulegali systemowi" ${ }^{\prime \prime}$.

Władysław Wolter mówił o wywieraniu presji na sąd przez uaktywniające się społeczeństwo. Zalecał, by więcej energii poświęcić przyszłości niż rozliczaniu przeszłości ${ }^{41}$. Przeciwnego zdania był Zenon Zaniewicki, który uważał, że najważniejszy jest rozrachunek z przeszłością, który umożliwi odzyskanie zaufania społeczeństwa i odbudowę autorytetu sądownictwa. Wspomniał o konieczności zmian w systemie prawa, które umożliwią realizację materialnej praworządności. Poparł propozycję podporządkowania prokuratury ministerstwu sprawiedliwości. Postulował z kolei przywrócenie instytucji sędziów śledczych, oddanie prawa do decydowania o aresztowaniu sądom oraz zwiększenie liczby etatów sędziowskich ${ }^{42}$. Aleksander Bachrach zaś wypowiedział się przeciwko wyciąganiu konsekwencji wobec osób, które ponosiły odpowiedzialność choćby największą, ale "tylko" moralną, polityczną i zawodową, nie dopuściły się jednak przestępstw w świetle ówcześnie obowiązującego prawa ${ }^{43}$. Zabierający głos prezentowali różne punkty widzenia, których bogactwo świadczy o samodzielności myślenia ich autorów; również o tym, iż dotychczas nie mieli możliwości mówienia o wielu sprawach otwarcie, ucierania stanowisk i dochodzenia do wspólnie wypracowanych, powszechnie akceptowanych rozwiązań. Wskazywali na to, jak owa odwilżowa atmosfera wpływała na społeczeństwo i organa stosujące prawo i jakie rodziło to $\mathrm{w}$ ówczesnych realiach zagrożenia. Opisywali przejawy zmian, wiedząc, że nie wszystkie zasługują na pełną aprobatę i szukali najlepszych propozycji rozwiązań na przyszłość.

\section{Krytyka „błędów i wypaczeń"}

Najszersze katalogi zarzutów przedstawili w swoich już przytaczanych artykułach, w pierwszym numerze "Prawa i Życia”, Gustaw Auscaler i Jerzy Jodłowski. Pierwszy z nich wskazał na wszechobecne zakłamanie oraz konformizm wobec stanowienia i stosowania niesprawiedliwego prawa, a także oportunizm sędziów i urzędników. Czytając jego słowa można by sądzić, że pisze o sobie. Trudno ocenić, czy odpowiadało za to jego poczucie winy, czy też może chęć wykazania się wobec nowego prądu i wyparcia się własnych win. Przypomniał o naginaniu teorii do praktyki oraz o szkodliwym dogmatyzmie w prawie. Jego zdaniem bolączką systemu była niechęć rządzących do przyznania się do dotkliwych społecznie błędów w postaci licznych niesłusz-

\footnotetext{
40 J. Jodłowski, Sprawy na porządku dziennym, PiŻ 1956, nr 14, s. 2, 6.

41 W. Wolter, Dwa cele dyskusji, PiŻ 1956, nr 14, s. 2.

42 Z. Zaniewicki, O odzyskanie zaufania, PiŻ 1956, nr 14, s. 2.

43 A. Bachrach, Problem odpowiedzialności, PiŻ 1956, nr 17, s. 5.
} 
nie skazanych. Stwierdził, że zamiast dokonać rehabilitacji tych osób, władza woli uciąć sprawę amnestią. Starał się jednak częściowo bronić winnych, wskazując na jego zdaniem szczytne pobudki wielu z nich, gdyż uważał za takie ukrywanie zbrodni przed społeczeństwem, by nie budzić w nim wątpliwości co do nieskazitelności idei ustroju socjalistycznego ${ }^{44}$.

Z kolei Jodłowski skupił się na kwestiach związanych z funkcjonowaniem wymiaru sprawiedliwości, wyliczając jego bolączki: dyspozycyjność sędziów pozbawionych gwarancji niezawisłości, niewłaściwe metody dochodzenia przestępstw, system, jaki panował w aparacie bezpieczeństwa, zmuszający do złych praktyk nawet tych, którzy mieli opory oraz pozwalający na ekscesy tym, którzy takich oporów nie posiadali. Nałożyła się na to dodatkowo - twierdził szkodliwa teoria o zaostrzaniu się walki klasowej w miarę budowy socjalizmu. Auscaler i Jodłowski wierzyli, że walka klasowa toczy się. Wskazywali, że znosząc zasadę nieusuwalności sędziów, nie zrealizowano mającej ją zastąpić zasady wybieralności. Umożliwiło to kierownictwu ministerstwa sprawiedliwości wiele niewłaściwych posunięć i usunięcie wielu bardzo dobrych sędziów, wywodzących się ze średniego i starszego pokolenia prawników. Wszystkie zaś z wymienionych nieprawidłowości doprowadziły do bardzo dotkliwego społecznie i politycznie spadku autorytetu sądownictwa w społeczeństwie ${ }^{45}$.

Stefan Gorecki wskazał na jeszcze jeden sposób wywierania presji na wymiar sprawiedliwości. Narzędziem był „Biuletyn Ministerstwa Sprawiedliwości", w którym de facto formułowano konkretne zalecenia wobec wydawanych wyroków. Zauważył: „nie trzeba sądzić surowo ani łagodnie; trzeba sądzić sprawiedliwie i mądrze [...] śmiało można zaryzykować twierdzenia, że sprawiedliwość jest dla jego autorów [Biuletynu - K.Ż.] synonimem surowości represji karnej" ${ }^{46}$.

\section{Niezawisłość sędziowska jako warunek konieczny praworządności}

W zakresie zapewnienia praworządności w życiu państwowym główny ciężar urzeczywistniania tej zasady kładziono na zapewnienie niezawisłości sędziów, niezależności sądów oraz kontrolę administracji. „Mieszkańców naszego kraju, interesują najbardziej dwie sprawy: podniesienie stopy życiowej i zabezpieczenie praworządności [...] kluczowym problemem wymiaru sprawiedliwości jest problem niezawisłości sędziów [...] Nie było z tym dobrze

\footnotetext{
44 G. Auscaler, op. cit.

45 J. Jodłowski, Aby praworządność nie była łamana..., s. 1.

46 S. Gorecki, Do użytku stużbowego, PiŻ 1956, nr 1, s. 4, 7.
} 
przed III Plenum i przed XX Zjazdem, nie jest z tym dobrze jeszcze i dzisiaj" 47 - podsumowywano w maju 1956 roku. Wywieranie nacisków miało miejsce nadal, zmieniły się forma $\mathrm{i}$ ton $\mathrm{w}$ jakim były formułowane. Niezawisłość sędziowską określano jako obowiązek sędziego i konstytucyjną gwarancję praw obywateli. Inteligentnie wybrnięto z politycznych zastrzeżeń wobec apolityczności i podległości sędziów tylko ustawom, wysunięto bowiem argument, że w ustroju socjalistycznym nie ma ustaw sprzecznych z linią partii. Przywrócić niezawisłość mogłoby - twierdzono - zrealizowanie konstytucyjnej zasady wybieralności sędziów, droga ta jednak, jak wykazywano, miała swoje mankamenty. Zaliczano do nich: obawę o fasadowość wyborów, dobór kandydatów oraz podważającą niezawisłość troskę o reelekcję․ Stwierdzono, że winni zachwiania autorytetu sądownictwa w społeczeństwie muszą odejść z sądownictwa oraz postulowano wykorzystanie braku zasady nieusuwalności sędziów w celu wyeliminowania osób niekompetentnych. W czasie obrad Plenum Zarządu Głównego ZPP Marian Mazur zauważył, iż ówczesne ustawodawstwo nosiło cechy prawa stanu wyjątkowego, zawieszającego liczne swobody obywatelskie ${ }^{49}$.

Na majowym plenum ZG ZPP (12-13 maja 1956 roku) Jodłowski poruszył problem niezawisłości sędziowskiej: nacisków zewnętrznych i wewnątrzsądowych, trybu powoływania, a zwłaszcza usuwania sędziów, niezależności materialnej. Przypomniał o obowiązującym dekrecie z 1946 roku, pozwalającym zwalniać sędziów jak urzędników z trzymiesięcznym okresem wypowiedzenia, a także o potrzebie zwiększenia liczby etatów sędziowskich, prokuratorskich i aplikanckich, aby sądy mogły sprostać stawianym im zadaniom. Poruszył zagadnienie zwiększenia środków materialnych na wyposażenie sądów. Wskazał jako cel, wokół którego należy skoncentrować dyskusję - ochronę praw obywateli przed lekceważeniem i nadużyciami administracji, ponieważ jego zdaniem - istniejące przepisy są niewystarczające, a nawet te istniejące są często odrzucane jako pochodzące $\mathrm{z}$ okresu międzywojennego. W istniejącym stanie rzeczy wskazał na nieskuteczność kontroli instancyjnej oraz ograniczoną skuteczność instytucji skarg i zażaleń, postulował potrzebę wprowadzenia nieokreślonej bliżej formy sądowej (sprawowanej przez sądy powszechne) kontroli nad działalnością i orzecznictwem władz i organów administracyjnych ${ }^{50}$. W tym samym tonie wypowiadał się Marian Mazur ${ }^{51}$, zwracając uwagę na ko-

47 Kierunek Działania. Notatki z Plenum Z. Gł. Z. P. P., PiŻ 1956, nr 2, s. 1. Plenum odbywało się 12 i 13 maja.

48 Ibidem.

49 Ibidem.

50 J. Jodłowski, Gwarancje na przyszłość, PiŻ 1956, nr 3, s. 7.

51 Marian Mazur (1910-1974) - działacz KPP oddelegowany do PPS-Lewicy, adwokat, 1946-1950 prezes Sądu Okręgowego, a następnie Apelacyjnego w Lublinie, 1950 - prezes Sądu Apelacyj- 
nieczność skończenia z dotychczasową „okrojoną praworządnością jak gdyby stanu wyjątkowego" i odbudowania normalnej, pokojowej praworządności ${ }^{52}$. Kolejne głosy również były poświęcone problemowi niezawisłości sędziów. Zenon Zaniewicki zwrócił dodatkowo uwagę na niewłaściwe praktyki działań instancji partyjnych wobec sędziów i zagrożenia płynące z wybieralności, czyli uzależnienie od czynników miejscowych ${ }^{53}$. Auscaler zaś jednoznacznie opowiedział się za wybieralnością sędziów przez obywateli, aby odpowiadali przed swoimi wyborcami, ponieważ bez tego nie ma mowy o prawdziwej demokratyzacji. Zgodnie z powszechnym poglądem zgadzał się, iż niezawisłość nie oznacza niezawisłości od socjalizmu czy linii partii dyktatury proletariatu, linii pojmowanej właściwie nie jako opinia tej czy innej partyjnej instancji czy działacza, ponieważ „sędzia jest współtwórcą linii Partii właśnie przez niezawisłość sądzenia" ${ }^{54}$. Bachrach w interesujący sposób rozróżnił zasięganie rady przez sędziego u członków partii i innych sędziów, których darzył zaufaniem. Ostatecznie jednak decydującego zgodnie $\mathrm{z}$ własnym osądem, co uznał za zjawisko pozytywne, przeciwstawiając je narzucaniu się z ową radą przez różne osoby w celu wywarcia wpływu na treść orzeczenia ${ }^{55}$.

Problemowi praworządności i niezawisłości był poświęcony wywiad z nowym ministrem sprawiedliwości, Zofią Wasilkowską ${ }^{56}$. Pani minister wyraziła opinię, iż wzmocnienie niezawisłości sędziów jest podstawowym postulatem w dziedzinie walki o pełną praworządność socjalistyczną. Środkami do tego prowadzącymi miały być: podniesienie autorytetu sędziego w społeczeństwie, zapewnienie nieingerencji zewnętrznej $\mathrm{i}$ wewnętrznej $\mathrm{w}$ wyrokowanie oraz zagwarantowanie sędziom, że nie będą dowolnie usuwani. Złożyła również oświadczenie, iż nie będzie korzystać $\mathrm{w}$ dotychczasowej formie z przepisów dekretu z 14 maja 1946 roku $^{57}$, umożliwiającego bez zachowania innych usta-

nego w Warszawie, 1950-1951 dyrektor departamentu w Ministerstwie Sprawiedliwości, w latach 1951-1952 prezes Izby Karnej Sądu Najwyższego oraz sędzia sekcji tajnej SN, 1951-1956 wiceprezes Głównej Komisji Arbitrażowej, czerwiec 1956 - maj 1961 zastępca Prokuratora Generalnego, 1961-1974 - prezes SN ds. ogólnych, prezes ZPP, pierwszy przewodniczący (od 18 marca $1957 \mathrm{r}$. zastąpił go Jan Wasilewski) komisji dla zbadania odpowiedzialności byłych pracowników GZI, NPW, NSW, M. Stanowska, A. Strzembosz, Sędziowie warszawscy w czasie próby 1981-1988, Warszawa 2005, s. 33; D. Maksimiuk, Rozliczanie stalinizmu na fali "odwilizy” 1956 roku. Dokumenty archiwalne dotyczące odpowiedzialności sędziów i prokuratorów wojskowych za łamanie praworządności w latach 1948-1954, „Miscellanea Historico-Iuridica” [MHI] 2010 t. IX, s. 111.

M. Mazur, Nie możemy czekać na naukowe syntezy, PiŻ 1956, nr 3, s. 7.

Z. Zaniewicki, W sadzie powiatowym, PiŻ 1956, nr 3, s. 7.

G. Auscaler, Sędziowie musza być wybierani, PiŻ 1956, nr 3, s. 7.

A. Bachrach, Autorytet rozumu czy autorytet stanowiska, PiŻ 1956, nr 3, s. 7.

Zofia Wasilkowska (1910-1996) - prawnik, działaczka związkowa oraz ruchu kobiet, posłanka na Sejm I i II kadencji, członek PPS, a następnie PZPR, marzec 1954 - marzec 1959 członek KC PZPR, kwiecień 1956 - luty 1957 minister sprawiedliwości, 1958-1981 sędzia SN, od 1981 w opozycji, T. Mołdawa, Ludzie władzy: 1944-1991, Warszawa 1991, s. 437. 
wowych warunków przenieść funkcjonariusza (w tym sędziego, prokuratora) na inne stanowisko lub w stan spoczynku bądź zwolnić ze służby po okresie trzymiesięcznego wypowiedzenia. Zmiany legislacyjne $w$ tej materii miał przynieść przygotowywany $\mathrm{w}$ ministerstwie projekt nowego prawa o ustroju sądów powszechnych. W projekcie regulacji płac „widełki” zastąpiono sztywnymi stawkami uposażenia, jednocześnie dokonując ich podwyższenia ${ }^{58}$. Minister zapowiadała również weryfikację zwolnień dokonanych na podstawie wspomnianego dekretu i naprawianie niesłusznych decyzji oraz zmiany $\mathrm{w}$ ustawie lub nową ustawę o ustroju adwokatury ${ }^{59}$.

Ignacy Iserles ${ }^{60}$ zaś poruszył pomijaną dotychczas sprawę około pięćdziesięciu tysięcy ławników ludowych. Zwracał uwagę na brak właściwej staranności przy ich wyborze, dotychczasowe deprecjonowanie ich roli w sądzie oraz niedocenianie możliwości kształtowania kultury prawnej w swoich środowiskach. Wskazał na brak reprezentacji inteligencji wśród ławników oraz postulował ich wybory powszechne $\mathrm{w}$ przeciwienstwie do dotychczasowych „wyborów” w "trybie urzędowym”, o których nie zawsze wiedzieli nawet sami kandydaci ${ }^{61}$. Wykazywał tym samym ich fasadowość, co pośrednio stanowiło poważny zarzut wobec całego systemu, gdyż takie „wybory” należały do jego specyfiki.

Pojawiły się również ciekawe propozycje kompromisowych rozwiązań godzących wybory sędziów z zasadą niezawisłości. Szymon Szumski proponował powszechne wybory sędziów na kadencję „dożywotnią”, zaś rolę społecznej kontroli miałaby spełniać możliwość ich odwołania, gdyby dali ku temu powód, w drodze dyscyplinarnej ${ }^{62}$. Inny model proponował Mieczysław Szerer: elekcji miałaby dokonywać Rada Państwa. Odnośnie zaś podważającej niezawisłość obawy o reelekcję przedstawiał dwie możliwe drogi: według jednej z nich w Radzie Państwa szybko mógłby się wykształcić zwyczaj re-

państwowych [do których zaliczono w rozumieniu tego dekretu: sędziów, prokuratorów, asesorów i aplikantów sądowych - K.Ż.] (Dz. U. 1946 nr 22, poz. 139, zmieniony: Dz. U. 1947 nr 65, poz. 382 i z $1950 \mathrm{nr} 44$, poz. 403). Zgodnie z jego postanowieniami właściwa władza naczelna mogła bez zachowania innych ustawowych warunków przenieść funkcjonariusza na inne stanowisko lub w stan spoczynku bądź zwolnić ze służby po okresie trzymiesięcznego wypowiedzenia. Pierwotnie to uprawnienie władzy naczelnej miało przysługiwać do końca 1947 r., następnie termin ten wydłużano do końca 1948 i 1950 r.; ostatecznie nowy termin miała ustalić Rada Ministrów w rozporządzeniu. Minister sprawiedliwości korzystał z tych uprawnienień, w praktyce zawsze za zgodą Rady Państwa, do 1962 r., A. Bereza, Sąd Najwyższy w Polsce Ludowej..., s. 228.

58 Zapowiedzi te zrealizowano w rozporządzeniu Rady Ministrów z 20 czerwca 1956 r. (Dz. U. 1956 nr 24, poz. 111).

59 Wywiad z Ministrem Sprawiedliwości - Zofią Wasilkowska, PiŻ 1956, nr 2, s. 3.

60 Ignacy Iserles - w latach 1951-1953 orzekał w sekcji tajnej SN, M. Stanowska, A. Strzembosz, op. cit., Warszawa 2005, s. 33.

61 I. Iserles, 50.000, PiŻ 1956, nr 7, s. 1.

62 S. Szumski, Wybierać czy mianować, PiŻ 1956, nr 8, s. 2. 
elekcji bądź też sformułowanie ustawowej zasady uzależniającej odwołanie sędziego w czasie kadencji lub odmowę reelekcji od orzeczenia specjalnej komisji dyscyplinarnej ${ }^{63}$.

Efektem tych dyskusji były skupiające się właśnie na zabezpieczeniu sędziowskiej niezawisłości Tezy do dyskusji w sprawie organizacji sądów, opracowane przez zespół prawników na zlecenie Prezydium ZG ZPP. Tezy, dość rozbudowane, stanowią podsumowanie wcześniej już wyrażonych stanowisk. Mówiły one, że sędzia rzeczywiście niezawisły powinien posiadać umiejętność stosowania ustaw $\mathrm{w}$ interesie mas zgodnie $\mathrm{z}$ socjalistycznym sumieniem, cechy te miałoby gwarantować określenie wymogów formalnych wobec kandydatów na to stanowisko. Mianowania powinna dokonywać Rada Państwa. Postulowano wprowadzenie zasady nieusuwalności sędziów, poza określonymi wypadkami. Proponowano utworzenie z sędziów Sądu Najwyższego komisji weryfikacyjnej, opiniującej wnioski ministra sprawiedliwości do Rady Państwa o zwolnienie sędziów nieposiadających odpowiednich kwalifikacji. Walka o praworządność zgodnie $\mathrm{z}$ jedną $\mathrm{z}$ tez powinna polegać na uaktywnieniu ławników ludowych, chciano to osiągnąć poprzez podniesienie wymagań wobec kandydatów na ławników oraz przyznanie im odpowiedniego wynagrodzenia ${ }^{64}$.

\section{Dyskusja na temat pożądanych form kontroli administracji publicznej}

Równie doniosłym sposobem zapewnienia realizacji praworządności miała być skuteczna kontrola administracji według kryterium legalności. W materii tej ujawniło się wiele rozbieżnych koncepcji. Jerzy Starościak ${ }^{65}$ zaproponował $^{2}$ umożliwienie obywatelowi i prokuratorowi zaskarżania decyzji administracyjnych do sądu. Na tym gruncie powstał z kolei spór, jaki to miałby być sąd, powszechny czy szczególny - sąd administracyjny ${ }^{66}$. Zdaniem Emanuela Iserzona ${ }^{67}$ skuteczną kontrolę pod kątem praworządności mogły zapewnić proku-

M. Szerer, Problem czy dogmat, PiŻ 1956, nr 6, s. 3.

Tezy do dyskusji w sprawie organizacji sąów, PiŻ 1956, nr 13, s. 2.

Jerzy Zdzisław Starościak (1914-1974) - prawnik administratywista, 1939 - doktorat, działacz ruchu ludowego, 1945-1958 - pracował w biurze Krajowej Rady Narodowej, a następnie kancelarii Rady Państwa, równocześnie (1945-1957) na Uniwersytecie Warszawskim, od 1947 w Akademii Nauk Politycznych, 1948 - habilitacja, od 1950 na UW jako profesor nadzwyczajny, 1958 - profesor zwyczajny, pracownik Instytutu Nauk Prawnych PAN, w latach 1972-1976 poseł na Sejm PRL, A. Szklarska-Lohmannowa, Starościak Jerzy Zdzisław, [w:] Polski Stownik Biograficzny, t. XLII/3, z. 174, Warszawa - Kraków 2004, s. 345-347.

Kierunek dziatania..., s. 1, 7.

Emanuel Iserzon (1893-1985) - polski prawnik, specjalista w zakresie prawa administracyj- 
ratura i sąd. Przedstawiając stan panujący w administracji, pisał o „entuzjastach operatywności” i „donkiszotach” praworządności. Stwierdził, iż w razie konfliktu celowości i praworządności pierwszeństwo należy dać praworządności, aczkolwiek ,Wstrzymanie się z wykonaniem konkretnego zadania w imię praworządności nie oznacza rezygnacji z konieczności osiągnięcia koniecznych celów państwowych. Ujawniona sprzeczność nakazuje doprowadzić do harmonii między celowością a praworządnością przez dokonanie zmian w planowaniu, lub samym stanie prawnym". W swoich rozważaniach nadmienił, iż kontrolę decyzji administracyjnych z punktu widzenia praworządności, oderwaną od celowości, mogą również sprawować sądy ${ }^{68}$.

Do problemu niskiej skuteczności prokuratorskiego nadzoru ogólnego odniósł się także prokurator generalny, Marian Rybicki ${ }^{69}$. Przyczyny widział w ograniczeniu nadzoru ogólnego tylko do organów terenowych, co „przy bardzo wysokim wciąż jeszcze stopniu centralizacji" pozostawiało poza kontrolą niezliczone instrukcje, okólniki czy zarządzenia wydawane organom terenowym przez władze centralne. Wskazywał na nieposiadanie przez prokuraturę konkretnych kompetencji, w wyniku czego za „bogatą fasadą konstytucyjną" nie stała możliwość skutecznego działania prokuratorów, ujęta w „określone formy prawne (terminy, sankcje itp.)"70. Wątek ten poruszył również Marian Mazur, pisząc o zbyt szeroko i mało konkretnie zakreślonych granicach prokuratorskiego nadzoru ogólnego ${ }^{71}$, co było źródłem jego nieskuteczności. Podsumował, iż „prokurator winien wejrzeć wszędzie, czuwać nad wszystkim, od-

nego, a zwłaszcza procedury administracyjnej; promotorem jego doktoratu z prawa karnego był prof. Wacław Makowski; w latach 1952-1956 kierownik Katedry Prawa Administracyjnego UMCS; 1956 - nominacja na docenta. Dążył do przestrzegania praworządności w administracji, a także do wprowadzenia sądowej kontroli decyzji administracyjnych, J. Szreniawski, Emanuel Iserzon, [w:] Profesorowie Wydziału Prawa i Administracji UMCS 1949-2009, red. A. Przyborowska-Klimczak, Lublin 2009, s. 106-115. Marian Rybicki (1915-1987) - polski prawnik, zajmował się różnymi dziedzinami prawa w ich
powiązaniu z charakterem i funkcjami państwa, członek PPS, a następnie PZPR, grudzień 1948 -
listopad 1968 członek KC PZPR, listopad 1952 - kwiecień 1956 sekretarz Rady Państwa, 20 czerwca KC PZPR (19-21 października 1956 r.) powołany w skład komisji do zbadania odpowiedzialności za praktyki służby bezpieczeństwa w okresie przedpaździernikowym, A. Kochański, Rybicki Marian, [w:] Polski Słownik Biograficzny, t. XXXIII/2, z. 137, Wrocław - Warszawa - Kraków 1991, s. $312-314$. 1956 - luty 1957 prokurator generalny PRL, 27 lutego 1957 - 25 czerwca 1965 minister sprawieWywiad z Prokuratorem Generalnym Marianem Rybickim, PiŻ 1956, nr 3, s. 3.

Nadzór ogólny - „W świetle postanowień ustawy o prokuraturze istota nadzoru ogólnego polegała na czuwaniu nad zgodnością aktów i innych czynności określonych władz, organów i instytucji z przepisami prawa oraz na sprawowaniu nadzoru nad ścisłym przestrzeganiem przepisów prawa przez wszystkich obywateli", M. Łysko, Prokuratorski nadzór ogólny w Polsce w latach 1950-1967, Białystok 2006, s. 34. Marian Rybicki (1915-1987) - polski prawnik, zajmował się różnymi dziedzinami prawa w ich
powiązaniu z charakterem i funkcjami państwa, członek PPS, a następnie PZPR, grudzień 1948 -
listopad 1968 członek KC PZPR, listopad 1952 - kwiecień 1956 sekretarz Rady Państwa, 20 czerwca

$$
\text { s. }
$$


powiadać za wszystko", co prowadziło go do stwierdzenia wyrażonego w tytule "Gdy «wszystko» oznacza «nic»"72.

Następnie, naczelnym wątkiem dyskusji o zapewnieniu realizacji praworządności poprzez kontrolę administracji stała się kwestia, czy rolę tę mają pełnić sądy szczególne, czy sądy powszechne oraz jaki zakres ma mieć kontrola $^{73}$. Na łamach pisma zamieszczono opracowane przez komisję ZPP (Jerzy Starościak - przewodniczący, Emanuel Iserzon, L. Krotkiewska, Józef Litwin i Jerzy Stembrowicz) tezy, mające rozwinąć dyskusję o konkretnych aspektach rozszerzenia udziału sądów w kontroli praworządności działania administracji: (I) rozszerzenie uprawnień prokuratury oraz włączenie sądów do wykonywania kontroli nad administracją w zakresie odpowiadającym możliwościom państwa, (II) skargi rozpatrywać by miały specjalne wydziały sądów powszechnych oraz odrębna izba Sądu Najwyższego bądź wyłącznie nowa izba Sądu Najwyższego (VI), (III) skarga przysługiwałaby po wyczerpaniu środków odwoławczych, (IV) skargi mogliby wnosić obywatele, przedstawiciele osób prawnych oraz prokuratorzy, (V) sąd dysponowałby tylko uprawnieniami kasacyjnymi bez prawa merytorycznego rozstrzygania sprawy, (VII) konieczność zabezpieczenia sądów przed nadmierną liczbą skarg, (VIII) sądowa kontrola nie pomniejszałaby uprawnień Rady Państwa do powszechnie obowiązującej interpretacji prawa, (IX) skodyfikowanie postępowania administracyjnego oraz publikowanie i poddawanie pod dyskusję projektów przepisów regulujących postępowanie administracyjne ze względu na ich podstawowe znaczenie $^{74}$. Józef Litwin ${ }^{75}$ postulował jak najszybsze działania, tak by jeszcze w 1957 roku zaczęły działać sądy administracyjne ${ }^{76}$. Dyskusja poświęcona kontroli administracji świadczy niestety o tym, że autorzy, odczuwając swobodę, jaką dała im "odwilż”, oderwali się od rzeczywistości. Snuli nierealne jak się okazało projekty. Nie wyczuli, że okres przesilenia mija; system nie jest taki sam, ale to ten sam system, a zaproponowane rozwiązania się $\mathrm{w}$ nim nie mieszczą.

72 M. Mazur, Gdy „wszystko” oznacza „nic”, PiŻ 1956, nr 10, s. 1.

73 O dyskusji na temat sądownictwa administracyjnego w latach 1945-1980 zob. M. Wyrzykowski, Sąownictwo administracyjne w PRL, Warszawa 1983, s. 28-45.

74 Skargi i zażalenia albo kontrola sądowa, PiŻ 1956, nr 6, s. 3.

75 Józef Litwin (1904-1966) - prawnik, jego zainteresowania obejmowały: prawo administracyjne, pogranicza prawa administracyjnego oraz cywilnego, a także zagadnienia prawne w literaturze pięknej; w 1947 r. obronił doktorat, od 1950 - profesor nadzwyczajny oraz od 1959 profesor zwyczajny na Uniwersytecie Łódzkim, członek Komitetu Nauk Prawnych PAN od momentu jego powołania (1952), członek Komisji Kodyfikacyjnej, wieloletni członek ZG ZPP. Od 1945 r. członek PPS, a następnie PZPR, H. Grajewski, Litwin Józef, [w:] Polski Słownik Biograficzny, t. XVII/4, z. 75, Wrocław - Warszawa - Kraków - Gdańsk 1972, s. 489-490.

76 J. Litwin, Czas przystąić do realizacji, PiŻ 1956, nr 9, s. 3. 


\section{Gorączka 1956 roku kończy się}

„Prawo i Życie” jako organ ZPP zajmowało się publicystyką w ograniczonym zakresie. Odnosiło się jedynie do najważniejszych z zachodzących wydarzeń, zaś do wielu innych - ze względu na ich prawne aspekty. Na bieżąco informowało o działalności władz centralnych i oddziałów lokalnych ZPP. Do wydarzeń czerwcowych czy październikowych odnoszono się głównie pośrednio $\mathrm{w}$ tekstach poświęconych innym zagadnieniom. Bezpośrednio poświęcano tym społecznie i politycznie doniosłym wydarzeniom pojedyncze, niezbyt wyeksponowane artykuły, choćby w porównaniu z okolicznościowymi tekstami z okazji rocznicy rewolucji październikowej. O zaszłej zmianie kierownictwa państwa pisano, podsumowując dotychczasowe wydarzenia: „Zwycięstwo to zrodził twórczy ferment myśli politycznej, idąca szeroką falą przez wszystkie dziedziny naszego życia ostra i bezwzględna krytyka stalinizmu, jego wszystkich błędów, zwyrodnień oraz zbrodni [...] Mieliśmy bowiem konstytucję $\mathrm{i}$ w niej zagwarantowane swobody obywatelskie, a obok działy się bezprawia"77.

W roku 1957 nadal toczyła się dyskusja, w której najwięcej miejsca poświęcono sądownictwu administracyjnemu. Wiemy, że dla jego utworzenia zmaterializowała się dopiero $\mathrm{w}$ ustawie z 1980 roku $^{78}$. Opadały już emocje, ważne zmiany polityczne już miały miejsce. Rozpoczęła się trwająca nadal w 1957 roku akcja rehabilitacyjna ${ }^{79}$. W 1956 roku powołano kilka komisji badających: odpowiedzialność byłych pracowników Głównego Zarządu Informacji (tzw. Komisja Mazura), odpowiedzialność partyjną za łamanie prawa przez funkcjonariuszy organów bezpieczeństwa; przejawy łamania praworządności przez pracowników Prokuratury Generalnej i Prokuratury m.st. Warszawy, działalność tzw. sekcji tajnej Sądu Wojewódzkiego m.st. Warszawy. Jednak aż do 1989 roku przed sądem nie postawiono żadnego sędziego ani prokuratora, aktywnych $\mathrm{w}$ latach stalinowskich ${ }^{80}$. W listopadzie 1956 roku została uchwalona ustawa o odpowiedzialności Państwa za szkody wyrządzone przez funkcjonariuszy państwowych ${ }^{81}$. Był to wielki krok naprzód, gdyż w latach 1950-1956 skarb państwa nie ponosił praktycznie odpowiedzialności cywilnej za działania w sferze władczej ${ }^{82}$, jedynie czysto teoretycznie obowiązywały

77 J. Piórkowski, Poczatek drogi, PiŻ 1956, nr 14, s. 1.

78 Dz. U. 1980 nr 4, poz. 8.

79 D. Maksimiuk, Problem rehabilitacji w latach 1956-1957, MHI 2009, t. VIII, s. 223-234.

80 Eadem, Rozliczanie stalinizmu na fali „odwilży” 1956 roku. Dokumenty archiwalne dotyczace odpowiedzialności sędziów i prokuratorów wojskowych za łamanie praworządności w latach 1948-1954, MHI 2010, t. IX, s. 111-112.

81 Dz. U. 1956 nr 54, poz. 243.

82 Obecnie kwestię tę regulują art. 417, 417[1], 417[2], 421 kodeksu cywilnego oraz art. 552-559 kodeksu postępowania karnego. 
przepisy kodeksu postępowania karnego z 1928 roku $^{83}$ w zakresie roszczeń odszkodowawczych z tytułu niesłusznego skazania ${ }^{84}$. Pod koniec 1956 roku Komisja prawa administracyjnego przy ZG ZPP opracowała projekt kodeksu postępowania administracyjnego. W 1958 roku powstała komisja ministerialna i ostatecznie w 1960 doszło do uchwalenia kodeksu postępowania administracyjnego przez Sejm ${ }^{85}$. Kodeks stał się narzędziem poprawy jakości funkcjonowania administracji, ale sądownictwo administracyjne nie zostało zrealizowane.

\section{Ocena roli „Prawa i Życia"}

"Prawo i Życie”, będąc organem prasowym ZPP, powstało w ważnym momencie dziejowym. Wypełniło w 1956 roku swe zadanie walki o praworządność $\mathrm{w}$ zakresie, jaki był zapewne nie do pomyślenia w momencie przystępowania do tworzenia tego czasopisma na przełomie lat 1955 i 1956. Jedną z najważniejszych przyczyn zachodzących zmian, która jednocześnie współgrała z powstawaniem pisma o tak określonych celach, był referat Nikity Chruszczowa wygłoszony na XX Zjeździe KPZR (14-25 lutego 1956 roku). Dzięki temu, że czasopismo zaczęło się ukazywać w tym właśnie czasie, miało szansę zaistnieć dzięki odważnemu udziałowi w nabierającej znaczenia dyskusji i tę szansę bez wątpienia wykorzystało. Było forum, gdzie wielu prawników mogło zabrać odważnie głos i dyskutować o koniecznych zmianach, które niestety w większości okazywały się tylko pozornie osiągalne. Na jego łamach można było zaobserwować efekty „nawrócenia” m.in. sędziów sekcji tajnej Sądu Najwyższego, osobiście odpowiedzialnych i biorących udział w niektórych z krytykowanych praktyk: Gustawa Auscalera, Aleksandra Bachracha, Mariana Mazura i Ignacego Iserlesa. Wielce interesujące i wymagające dalszych, zapewne interdyscyplinarnych, badań jest zagadnienie, kiedy i w jakim stopniu działający wówczas prawnicy wyrażali w poszczególnych tekstach w prasie, czy pracach w Komisji Kodyfikacyjnej zdanie własne, a kiedy ich wypowiedzi były podporządkowane aktualnej koniunkturze politycznej.

„Prawo i Życie” odegrało bardzo ważną rolę jako trybuna dla merytorycznych dyskusji prawniczych, naświetlania kwestii praworządności z wielu stron i punktów widzenia. Ze względu na dynamikę sytuacji owe odwilżowe zdobycze, które zdawały się być na wyciągnięcie ręki, jak np. sądownictwo administracyjne, okazały się mirażami. Warto zaznaczyć, jak wielki przełom stanowiły tak daleko idące dyskusje, mające ciągle w tle "stalinizm" i „beriowszczyznę", jak i to, że odbywały się w państwie w rzeczywistości niedemokratycznym,

83 Dz. U. 1928 nr 33, poz. 313.

84 P. Cioch, Odpowiedzialność Skarbu Państwa z tytułu niesłusznego skazania, Warszawa 2007, s. 42.

85 E. Iserzon, J. Starościak, Kodeks postępowania administracyjnego - komentarz, Warszawa 1961, s. 3-6. 
które jednak w roku 1956 przeżywało daleko idącą liberalizację, odmieniającą trwale PRL. Koniec odwilży (przez poszczególnych autorów różnie datowany w związku z przypisywaniem przez nich zasadniczego znaczenia innym wydarzeniom; październik 1956 - 1958) był naturalnym następstwem konieczności usunięcia dysonansu pomiędzy coraz dalej posuwającą się liberalizacją i słabnięciem ideologii, a realną siłą, jaką nadal dysponowała PZPR i brakiem szans na oddanie władzy przez komunistów. Odwilż zakończyła się, pozostawiając jednak niezatarty ślad. To właśnie przemiany zapoczątkowane po śmierci Stalina, a w PRL znajdujące najpełniejszy wymiar właśnie w roku 1956, pozbawiły ustrój cech totalitarnych, czyniąc PRL państwem autorytarnym, „znośniejszym" do życia ${ }^{86}$.

„Prawo i Życie” powstało w ważnym momencie historycznym, było organem prasowym ZPP, co warunkowało jego wysoki poziom merytoryczny, ale jednocześnie bliskie związanie $\mathrm{z}$ władzą, a tym samym dopasowywanie się do linii rządzących.

\section{Ewolucja pojęcia praworządności po 1956 roku}

Po 1956 roku mamy do czynienia ze zmodyfikowanym rozumieniem praworządności. Andrzej Burda w 1965 roku definiował praworządność jako stan faktyczny, stan rzeczy w życiu państwowym, charakteryzujący się metodą realizowania władzy państwowej $\mathrm{w}$ najszerszym znaczeniu tego słowa, polegający na tym, że wszelka podległość obywatela władzy państwowej uregulowana jest przez prawo, a odnośne regulacje są ściśle przestrzegane, na straży czego stoją właściwe, ustanowione przez prawo gwarancje. Zagadnienie objęcia przestrzegania prawa przez obywateli zakresem pojęcia praworządności budziło, jak wskazywał, liczne wątpliwości: naruszenie prawa przez obywatela potwierdza rację bytu porządku prawnego; gdy dopuści się takiego naruszenia organ państwowy to podważa rację bytu porządku prawnego - naruszenia mają więc różny ciężar gatunkowy ${ }^{87}$. Najważniejszymi skutkami dyskusji, której poświęcone są powyższe wywody $\mathrm{w}$ zakresie rozumienia pojęcia praworządności, są dwie zmiany w sposobie jego rozumienia. Pierwszą, podstawową, jest odrzucenie koncepcji ostrzy praworządności, co wynikało również z jej stalinowskiego rodowodu. Po drugie, zaczęto kwestionować odnoszenie praworządności do zachowań obywateli, wiążąc ją wyłącznie z prawidłowym działaniem państwa, zwłaszcza w sferze stosowania prawa. Te dwie zmiany w znaczącym zakresie zatarły różnice pomiędzy dotychczas ostro rozgrani-

86 L. Mażewski, Posttotalitarny autorytaryzm PRL 1956-1989: analiza ustrojowopolityczna, Warszawa 2010.

87 A. Burda, Demokracja i praworzadność, Wrocław - Warszawa - Kraków 1965, s. 31-33, 40. 
czanymi praworządnościami - socjalistyczną i burżuazyjną. To właśnie w socjalistycznej Polsce uchwalono w 1960 roku kodeks postępowania administracyjnego, znacząco poprawiający pracę administracji publicznej, pomimo iż nie wszystkie państwa demokratyczne mogły wówczas pochwalić się posiadaniem aktu prawnego tego rodzaju.

\section{Wnioski}

Głównymi wątkami dyskusji nad szeroko rozumianą praworządnością były: rozumienie praworządności, krytyka poprzedniego okresu i wskazywanie konkretnych problemów oraz wynikające $\mathrm{z}$ chęci przeciwdziałania im postulaty ${ }^{88}$. Początkowo dyskusja koncentrowała się na sposobach zabezpieczenia sądownictwa przed patologiami, jakie miały miejsce wcześniej, czyli głównie "czy i jak" realizować zasadę niezależności sądów i niezawisłości sędziowskiej. W ramach tego wątku ujawniły się rozbieżne opinie w kwestii zadań sądownictwa w Polskiej Rzeczypospolitej Ludowej i ich realizacji. Jako że równie bolącą kwestią był dotkliwy społecznie brak podstawowych standardów $\mathrm{w}$ administracji oraz jej liczne nadużycia i braki, rozwinęła się gorąca polemika o sposobach kontroli działalności administracji z pozycji praworządności. Interesującym wątkiem był postulat wprowadzenia, czy raczej przywrócenia, sądowej kontroli administracji, zwłaszcza że komuniści u zarania Polski Ludowej deklarowali przywrócenie istniejącego w II RP sądownictwa administracyjnego. Mimo licznych postulatów godzących de facto $\mathrm{w}$ fundamenty istniejącego ustroju, liczni autorzy nie posuwali się do krytykowania socjalizmu jako takiego, wskazywali jedynie konkretne nieprawidłowości i sposoby zaradzenia im. Złudzeniem jest jednak sądzić, że publikowano wszystko, co autorzy pisali, a to tym samym pokazuje, że jednak w pewnym zakresie partia kontrolowała skalę krytyki. Przykładem może być wstrzymanie publikacji artykułu Mariana Mazura, wzywającego do ujawnienia i ukarania winnych zbrodni okresu stalinowskiego i poddanie go ocenie szefa Zarządu Sądownictwa Wojskowego, osobiście odpowiadającego za zbrodnie okresu stalinowskiego, który oczywiście wykreślił wszystkie wzmianki o nich. Zaś członek kolegium redakcyjnego skomentował to bezpośrednio: „Jak by Marian miał to wydrukowane, co napisał, to by nie dostał stanowiska, co dostanie [zastępcy Prokuratora Generalnego - K.Ż.]" 89 .

88 Bardzo liczne wypowiedzi, odnoszące się również pośrednio do problemu praworządności, pojawiały się w obszernej dyskusji na temat projektu kodeksu karnego. Wątek ów wyczerpująco został omówiony w: D. Maksimiuk, Rok 1956 w Polsce: sqdy, prokuratury, prawo karne, Białystok 2011 (rozprawa doktorska obroniona na Wydziale Prawa UwB, niepublikowana).

Eadem, Problem rehabilitacji w latach 1956-1957, MHI 2009, t. VIII, s. 301. 
Podsumowując, wydarzenia roku 1956 dały początek rozważaniom teoretycznym co do treści pojęcia praworządności, niezdeterminowanych już w takim stopniu wzorcami zza Bugu; „od tego momentu częstotliwość pojawiania się tego słowa w literaturze - i to zarówno w wersji rzeczownikowej, jak i przymiotnikowej - była swoistym barometrem nastrojów społecznych oraz politycznych" ${ }^{\prime 90}$. Kolejne przełomy polityczne w PRL wiązały się z częstszym odwoływaniem się do pojęcia praworządności. „Prawo i Życie”, związane z rządzącymi, wzięło udział w kolejnej gorącej dyskusji o praworządności na przełomie lat 1980/198191, która ostatecznie zaowocowała odrzuceniem socjalizmu i przyjęciem w III RP praworządności, wcześniej określanej jako burżuazyjna.

\section{Bibliografia}

Auscaler G., Myśli na co dzień, „Prawo i Życie” 1956, nr 1.

Auscaler G., Sędziowie muszą być wybierani, „Prawo i Życie” 1956, nr 3.

Bachrach A., Autorytet rozumu czy autorytet stanowiska, "Prawo i Życie” 1956, nr 3.

Bachrach A., Problem odpowiedzialności, „Prawo i Życie” 1956, nr 17.

Bereza A., Sąd Najwyższy w latach 1945-1962. Organizacja i działalność, Warszawa 2012.

Bereza A., Sąd Najwyższy w Polsce Ludowej, [w:] Sąd Najwyższy Rzeczypospolitej Polskiej. Historia i współczesność. Księga Jubileuszowa 90-lecia Sądu Najwyższego 1917-2007, red. A. Korobowicz, Toruń 2007.

Bielecki A., Jerzy Jodłowski 1909-2000, [w:] Profesorowie Wydziału Prawa i Administracji Uniwersytetu Warszawskiego 1808-2008, red. G. Bałtruszajtys, Warszawa 2008.

Błażyński Z., Mówi Józef Światło. Za kulisami bezpieki i partii 1940-1955, Warszawa 1990.

Burda A., Demokracja i praworządność, Wrocław - Warszawa - Kraków 1965.

Cioch P., Odpowiedzialność Skarbu Państwa z tytułu niesłusznego skazania, Warszawa 2007.

Gorecki S., Do użytku stużbowego, „Prawo i Życie” 1956, nr 1.

Grajewski H., Litwin Józef, [w:] Polski Słownik Biograficzny, t. XVII/4, z. 75, Wrocław - Warszawa - Kraków - Gdańsk 1972.

III Plenum Zarządu Głównego ZPP, „Prawo i Życie” 1956, nr 17.

90 M. Kordela, Państwo praworządne i państwo prawne-stosunek pojęć, [w:] Państwo prawa-demokratyczne państwo prawne. Antologia, red. J. Kowalski, Warszawa 2008, s. 118.

91 J. Kuisz, O pojmowaniu praworządności w Polskiej Rzeczypospolitej Ludowej w latach 1980-1981, CPH 2008, t. LX, z. 2, s. 331-361. 
Informacja o tygodniku prawno-społecznym "Prawo i Życie”, [w:] Prawo i prawnicy w trzydziestolecie Polskiej Rzeczpospolitej Ludowej (materiały z narady zrzeszeń prawniczych europejskich krajów socjalistycznych), Warszawa 1974.

Iserles I., 50.000, „Prawo i Życie” 1956, nr 7.

Iserles I., O adwokatach nie po raz pierwszy, „Prawo i Życie” 1956, nr 2.

Iserles I., W Poznaniu, „Prawo i Życie” 1956, nr 12.

Iserzon E., Prymat nakazu prawa, „Prawo i Życie” 1956, nr 3.

Iserzon E., Starościak J., Kodeks postępowania administracyjnego - komentarz, Warszawa 1961.

Izdebski Z., Miara praworządności, „Prawo i Życie” 1956, nr 11.

Jamróz A., Wprowadzenie do prawoznawstwa, Warszawa 2011.

Jodłowski J., Aby praworządność nie była łamana [Z przemówienia na VIII sesji sejmowej], „Prawo i Życie” 1956, nr 1.

Jodłowski J., Gwarancje na przyszłość, „Prawo i Życie” 1956, nr 3.

Jodłowski J., Sprawy na porzadku dziennym, „Prawo i Życie” 1956, nr 14.

Kallas M., Lityński A., Historia ustroju i prawa Polski Ludowej, Warszawa 2000.

Kierunek działania. Notatki z Plenum Z. Gt. Z. P. P., „Prawo i Życie” 1956, nr 2.

Kochański A., Rybicki Marian, [w:] Polski Słownik Biograficzny, t. XXXIII/2, z. 137, Wrocław - Warszawa - Kraków 1991.

Konarski M., Stembrowicz Jerzy, [w:] Polski Słownik Biograficzny, t. XLIII/3, z. 178, Warszawa - Kraków 2005.

Kordela M., Państwo praworzadne i państwo prawne - stosunek pojęć, [w:] Państwo prawa - demokratyczne państwo prawne. Antologia, red. J. Kowalski, Warszawa 2008.

Kuisz J., O pojmowaniu praworządności w Polskiej Rzeczypospolitej Ludowej w latach 1980-1981, „Czasopismo Prawno-Historyczne” 2008, t. LX, z. 2.

Litwin J., Czas przystapić do realizacji, „Prawo i Życie” 1956, nr 9.

Lityński A., O pojmowaniu praworządności socjalistycznej w Polsce Ludowej, "Czasopismo Prawno-Historyczne" 2007, t. LIX, z. 1.

Lityński A., O praworządności ludowej w Polsce 1944-1956 teoretycznych uwag kilka, [w:] Z dziejów prawa, cz. 8, Katowice 2006.

Łyczywek R., Etapowe prawdy, „Prawo i Życie” 1956, nr 6.

Łysko M., Prokuratorski nadzór ogólny na tle idei sądownictwa administracyjnego, "Miscellanea Historico-Iuridica" 2004, t. II.

Łysko M., Prokuratorski nadzór ogólny w Polsce w latach 1950-1967, Białystok 2006.

Maksimiuk D., Problem rehabilitacji w latach 1956-1957, „Miscellanea Historico-Iuridica" 2009, t. VIII.

Maksimiuk D., Rok 1956 w Polsce: sady, prokuratury, prawo karne, Białystok 2011 (rozprawa doktorska obroniona na Wydziale Prawa UwB, niepublikowana).

Maksimiuk D., Rozliczanie stalinizmu na fali „odwilży” 1956 roku. Dokumenty archiwalne dotyczace odpowiedzialności sędziów i prokuratorów wojskowych za łamanie praworządności w latach 1948-1954, „Miscellanea Historico-Iuridica” 2010, t. IX. 
Maksimiuk D., W sprawie demokratyzacji wymiaru sprawiedliwości. "Prawo i Życie” i inne czasopisma prawnicze w roku 1956 w Polsce, "Czasopismo Prawno-Historyczne" 2011, t. LXIII, z. 1.

Mazur M., Gdy "wszystko" oznacza „nic”, „Prawo i Życie” 1956, nr 10.

Mazur M., Nie możemy czekać na naukowe syntezy, "Prawo i Życie” 1956, nr 3.

Mażewski L., Posttotalitarny autorytaryzm PRL 1956-1989: analiza ustrojowopolityczna, Warszawa 2010.

Mołdawa T., Ludzie władzy: 1944-1991, Warszawa 1991.

Paczkowski A., Trzy twarze Józefa Światty, Warszawa 2009.

Piórkowski J., Początek drogi, „Prawo i Życie” 1956, nr 14.

Płużyński M., Stalinowscy uciekinierzy, „Najwyższy Czas” 2009, nr 48.

Podlaski H., Auscaler G., Jaroszyński M., Seidler G. L., Wróblewski J., Praworząność ludowa w świetle Konstytucji Polskiej Rzeczypospolitej Ludowej, [w:] Zagadnienia prawne konstytucji Polskiej Rzeczypospolitej Ludowej. Materiały Sesji Naukowej PAN 4-9 lipca 1953 r., red. G. Auscaler, t. 1, Warszawa 1954.

Przymusiński C., Prawa ekonomiczne sa silniejsze, „Prawo i Życie” 1956, nr 4.

Przymusiński C., Roboczy postulat, „Prawo i Życie” 1956, nr 8.

Skargi i zażalenia albo kontrola sądowa, „Prawo i Życie” 1956, nr 6.

Starościak Jerzy Zdzisław, [w:] Polski Słownik Biograficzny, t. XLII/3, z. 174, Warszawa - Kraków 2004.

Stembrowicz J., Granice kompetencji, „Prawo i Życie” 1956, nr 8.

Szerer M., Problem czy dogmat, „Prawo i Życie” 1956, nr 6.

Szreniawski J., Emanuel Iserzon, [w:] Profesorowie Wydziatu Prawa i Administracji UMCS 1949-2009, red. Anna Przyborowska-Klimczak, Lublin 2009.

Szumski S., Wybierać czy mianować, „Prawo i Życie” 1956, nr 8.

Tezy do dyskusji w sprawie organizacji sądów, „Prawo i Życie” 1956, nr 13.

Wolter W., Dwa cele dyskusji, „Prawo i Życie” 1956, nr 14.

Wolter W., Zagadnienie praworząności w prawie karnym, „Prawo i Życie” 1956, nr 2.

Wyrzykowski M., Sądownictwo Administracyjne w PRL, Warszawa 1983.

Wywiad z Ministrem Sprawiedliwości - Zofią Wasilkowska, „Prawo i Życie” 1956, nr 2.

Wywiad z Prokuratorem Generalnym Marianem Rybickim, „Prawo i Życie” 1956, nr 3.

Zaniewicki Z., O odzyskanie zaufania, „Prawo i Życie” 1956, nr 14.

Zaniewicki Z., W sądzie powiatowym, „Prawo i Życie” 1956, nr 3.

Zawadzki S., Co opóźnia realizację praworzadności, „Prawo i Życie” 1956, nr 4.

Исаев И. А., История государства и права России, Москва 2004. 